\title{
Microwave-assisted synthesis of benzimidazole and thiazolidinone derivatives as HIV-1 RT inhibitors
}

\author{
Angela Rao, Alba Chimirri, Stefania Ferro, Anna Maria Monforte, Pietro Monforte, ${ }^{*}$ and \\ Maria Zappalà
}

Dipartimento Farmaco-Chimico, Università di Messina, Viale Annunziata 98168, Messina, Italy E-mail: monforte@pharma.unime.it

\section{Dedicated to Professor Vincenzo Tortorella on the Occasion of his "Fuori Ruolo" status \\ (received 23 Dec 03; accepted 02 Mar 04; published on the web 05 Mar 04)}

\begin{abstract}
In this paper we describe the microwave-assisted synthesis of $1 H, 3 H$-thiazolo[3,4a]benzimidazoles, 2-aryl-1-benzylbenzimidazoles and 2,3-diaryl-1,3-thiazolidin-4-ones, which achieved reductions in reaction times, higher yields, cleaner reactions than for the previouslydescribed synthetic processes. In some cases eco-friendly solventless methodology has been used.
\end{abstract}

Keywords: $1 H, 3 H$-Thiazolo[3,4-a]benzimidazoles, 2-aryl-1-benzylbenzimidazoles, 2,3-diaryl1,3-thiazolidin-4-ones, microwave-assisted synthesis, anti-HIV agents

Chemistry is critical to drug discovery, especially at the lead optimization phase, but methods for the synthesis of organic compounds have remained essentially unchanged for decades. Since lead optimization time is usually very long with a very high manpower requirement, new ways to improve the efficiency, output and quality in this phase are always needed.

One feasible solution is microwave-assisted synthesis, which is in many ways superior to traditional heating: reactions are completed in minutes, yields are generally higher than those achievable by traditional means, chemistry unfeasible by conventional procedures might be performed. Furthermore, thanks to this method, heating is immediate and volumetric, the temperature is accurately controlled so that reactions can be more easily repeated. ${ }^{1,2}$

Microwave energy has been previously used in chemical application such as digestion and extraction processes; now, with the introduction of single-mode microwave reactors for organic synthesis, this technology is widely applied to drug discovery.

In view of the above, we planned to apply this new methodology in our research projects aimed at the discovery of new anti-AIDS drugs.

The etiological agent of AIDS, the immunodeficiency virus (HIV), is a retrovirus belonging to the lentivirus subfamily. The highly-active antiretroviral therapy (HAART) based on a 
combination of HIV-1 reverse transcriptase (RT) and protease inhibitors, is nowadays the most effective approach in the treatment of AIDS. ${ }^{3,4}$ However, side-effects and the clinical emergence of resistant mutants suggest that there will be an ever-increasing need for new enzyme inhibitors not only with good pharmacological profiles but also easy to synthesize at low cost.

In recent years, our research group has been engaged in the development of new nonnucleoside RT inhibitors (NNRTI) and has reported chemical and biological studies of various $1 H, 3 H$-thiazolo[3,4-a]benzimidazoles 1 (TBZs) (Figure 1) and their analogues as potent anti-HIV agents. ${ }^{5-8}$

Our lead compound, 1-(2,6-difluorophenyl)-1H,3H-thiazolo[3,4-a]benzimidazole (1a, NSC 625487), proved to be a highly potent inhibitor of HIV-1-induced cytopathic effect in a variety of human cell lines and inhibited the replication of various strains of HIV-1 including a zidovudineresistant strain (G910-6). ${ }^{8}$

SAR studies furnished significant information about the main structural requirements for anti-HIV activity. In particular, it was observed that: (i) the C-1 substituent is particularly important in interaction with the target; (ii) substitution on the benzene-fused ring influences the inhibitory potency depending on the nature and the position of the substituents; (iii) the presence of a methyl group at C-3 is favourable for the pharmacological profile.

In order to better define the SAR studies, considering compound 1a as template, we planned a series of modifications on the $1 \mathrm{H}, 3 \mathrm{H}$-thiazolo[3,4-a]benzimidazole skeleton.

The potential therapeutic utility of TBZs was hampered by the metabolic oxidation of the sulfur atom, thus the thiazole framework was eliminated and some 2-aryl-1benzylbenzimidazoles (2) were synthesized (Figure 1). ${ }^{9}$

We have recently performed molecular modelling studies which demonstrated that, similarly to other NNRTIs, the TBZ biological activity was associated with their assuming a butterfly-like conformation by means of a suitable spatial location of lipophilic groups important for the RT site binding. In particular, we observed that plausible pharmacophoric elements were: the benzene-fused ring, the dihalosubstituted aryl group at C-1 and the nitrogen atom of the thiazole nucleus. ${ }^{10}$ These structural requirements were successfully used as a framework for the design of 2,3-diaryl-1,3-thiazolidin-4-ones (3) leading to the discovery of a new class of potent anti-HIV-1 agents with marked RT inhibitory effects (Figure 1). ${ }^{10-13}$

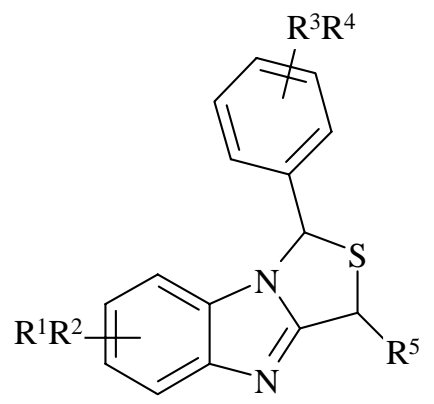

1

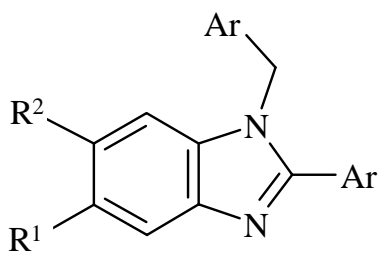

2<smiles>[R]c1[Y]c(N2C(=O)CSC2c2c([R])ccc([R])c2[R])c([X])c([R])c1</smiles>

3

Figure 1 
On the basis of these promising biological results, we considered it particularly interesting to optimise the synthetic approaches to our antiviral agents by using focused microwave irradiations.

In this paper we describe the microwave-assisted synthetic route to $1 H, 3 H$-thiazolo[3,4a]benzimidazoles (1), 2-aryl-1-benzylbenzimidazoles (2) and 2,3-diaryl-1,3-thiazolidin-4-ones (3) performed in order to achieve striking reductions in reaction times, better yields, cleaner reactions. Where possible this was accomplished in absence of solvent, which is a better and more practical eco-friendly alternative to existing methods.

The one-pot synthesis of $1 \mathrm{H}, 3 \mathrm{H}$-thiazolo[3,4-a]benzimidazoles (1a-e) was carried out by the condensation-cyclization reaction between the appropriate 1,2-phenylendiamine, a properlysubstituted aromatic aldehyde and 2-mercaptoacetic acid (Scheme 1). In the "classical” method, the reactions were performed in dry benzene at reflux for a long period of time (24-48h), often responsible for degradation processes and consequent low yields of isolated products, whereas with the application of microwave-assisted technology, the reaction is completed in only 12 minutes and the compounds, isolated by conventional work-up, are obtained in satisfactory yields, often higher than those achieved by the traditional method. Toluene, used as solvent instead of the more toxic benzene, is transparent to microwaves but in these reactions energy transfer may occur from the polar reactants to the solvent and the results may be different with respect to the traditional heating. In particular, specific effects of microwaves were described for the synthesis of 1,5-benzodiazepinones employing 1,2-phenylenediamine as starting material and xylene as solvent. ${ }^{14}$

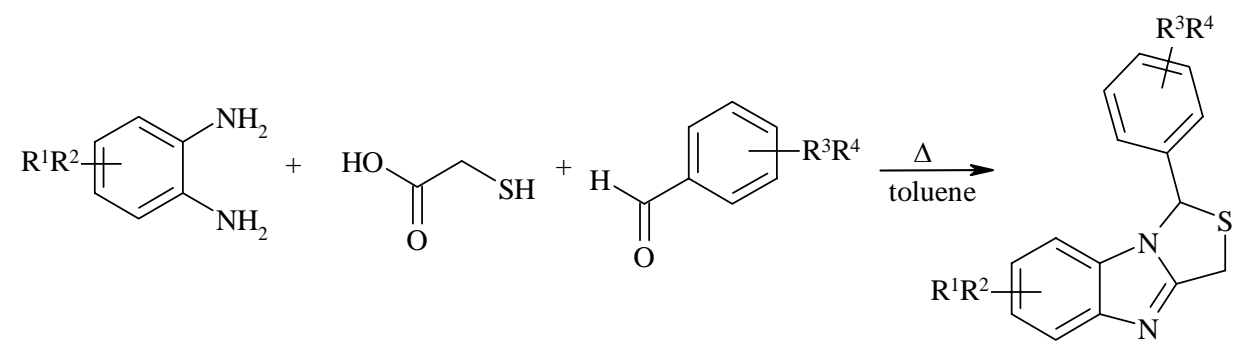

\begin{tabular}{ccccccccc}
\hline \multirow{2}{*}{ Comp } & \multirow{2}{*}{$\mathrm{R}^{1}$} & \multirow{2}{*}{$\mathrm{R}^{2}$} & \multirow{2}{*}{$\mathrm{R}^{3}$} & $\mathrm{R}^{4}$ & \multicolumn{2}{c}{ Reaction time } & \multicolumn{2}{c}{ Yield } \\
\cline { 6 - 9 } 1a & $\mathrm{H}$ & $\mathrm{H}$ & $2-\mathrm{F}$ & $6-\mathrm{F}$ & $48 \mathrm{~h}$ & $12 \mathrm{~min}$ & 92 & 60 \\
$\mathbf{1 b}$ & $\mathrm{H}$ & $\mathrm{H}$ & $3-\mathrm{NO}_{2}$ & $\mathrm{H}$ & $24 \mathrm{~h}$ & $12 \mathrm{~min}$ & 25 & 50 \\
1c & $6-\mathrm{Me}$ & $7-\mathrm{Me}$ & $2-\mathrm{F}$ & $6-\mathrm{F}$ & $24 \mathrm{~h}$ & $12 \mathrm{~min}$ & 36 & 40 \\
$\mathbf{1 d}$ & $5-\mathrm{Me}$ & $\mathrm{H}$ & $2-\mathrm{F}$ & $6-\mathrm{F}$ & $48 \mathrm{~h}$ & $12 \mathrm{~min}$ & 22 & 64 \\
1e & $8-\mathrm{Me}$ & $\mathrm{H}$ & $2-\mathrm{F}$ & $6-\mathrm{F}$ & $48 \mathrm{~h}$ & $12 \mathrm{~min}$ & 5 & 16 \\
\hline
\end{tabular}

A: conventional heating. B: microwave irradiation.

\section{Scheme 1}


The synthesis of 2-aryl-1-benzylbenzimidazoles (2a-b) was accomplished by reacting a 1,2phenylendiamine with an excess of 2,6-difluorobenzaldehyde in the presence of a catalytic amount of p-toluenesulfonic acid (Scheme 2). The reaction proceeds through the formation of 2arylbenzimidazoline, generated in situ from 1,2-phenylenediamine and the aromatic aldehyde. Thanks to the well-known reducing ability exhibited by this intermediate, the aldehyde is converted into the corresponding alcohol which in turn alkylates the 2-arylbenzimidazole formed in this redox process.

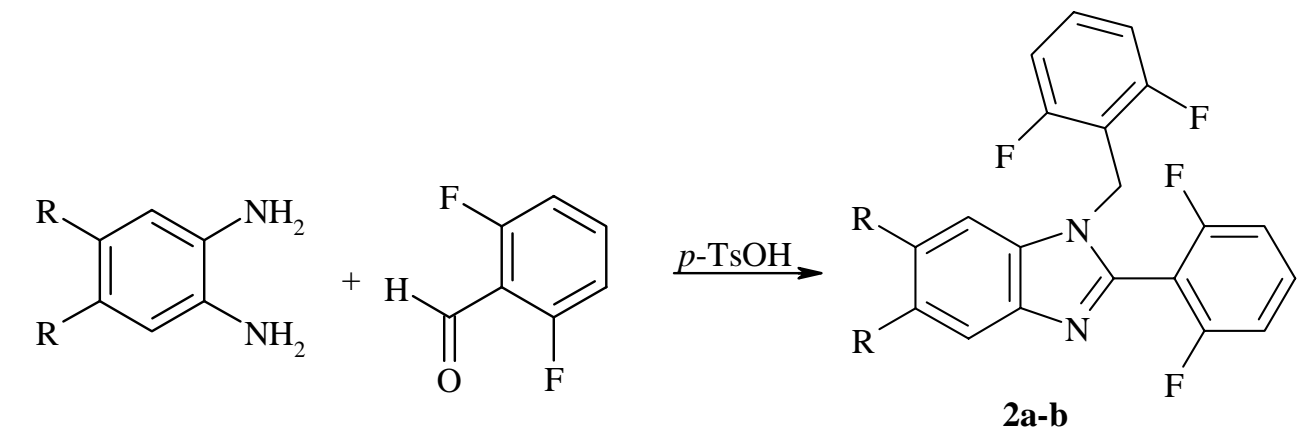

\begin{tabular}{cccccc}
\hline \multirow{2}{*}{ Comp } & R & \multicolumn{2}{c}{ Reaction time } & \multicolumn{2}{c}{ Yield \% } \\
\cline { 3 - 6 } & & A & B & A & B \\
\hline 2a & H & 2 h & 6 min & 20 & 70 \\
2b & Me & 2 h & 6 min & 70 & 72 \\
\hline
\end{tabular}

A: conventional heating. B: microwave irradiation.

\section{Scheme 2}

Applying microwave irradiation, the reaction was performed in ethanol for $\mathbf{2} \mathbf{b}$ and solventless for compound 2a in only 6 minutes. These results confirm that the focused microwave irradiation is a very effective technique for accelerating thermal organic reactions also in solvent-free conditions.

The synthesis of 2,3-diaryl-1,3-thiazolidin-4-ones (3a-e) was carried out by reacting an aromatic aldehyde with an equimolar amount of (hetero)aromatic amine in the presence of an excess of mercaptoacetic acid, as shown in scheme 3. Once more, the microwave-irradiation dramatically shortened the reaction times, affording the desired products in high yields. This approach was also applied under solvent-free conditions but in this case the compounds were isolated in unsatisfactory yields (i.e. 20-30\%).

In conclusion, we have developed a versatile and useful new access to different classes of anti-HIV agents using an efficient and simple methodology based on focused microwave irradiation. The most important result of this approach, compared with the previously-reported methods, is the optimization of yields and reaction times. The efficiency of the employed methodology can be explained by the fact that microwave energy is probably much higher than 
the activation energy necessary for each reaction so that reaction speeds are increased and yields higher.<smiles>[R]c1cc([R])[Y](N)c([R])c1</smiles>
3a-e

\begin{tabular}{ccccccccccccc}
\hline & & & & & & & & \multicolumn{2}{c}{ Reaction time } & \multicolumn{2}{c}{ Yield \% } \\
\cline { 7 - 11 } Comp & $\mathrm{X}$ & $\mathrm{Y}$ & $\mathrm{R}^{1}$ & $\mathrm{R}^{2}$ & $\mathrm{R}^{3}$ & $\mathrm{R}^{4}$ & $\mathrm{R}^{5}$ & $\mathrm{~A}$ & $\mathrm{~B}$ & $\mathrm{~A}$ & $\mathrm{~B}$ \\
\hline 3a & $\mathrm{CH}$ & $\mathrm{CH}$ & $\mathrm{Me}$ & $\mathrm{H}$ & $\mathrm{Cl}$ & $\mathrm{H}$ & $\mathrm{Cl}$ & $48 \mathrm{~h}$ & $12 \mathrm{~min}$ & 65 & 72 \\
3b & $\mathrm{CH}$ & $\mathrm{CH}$ & $\mathrm{OMe}$ & $\mathrm{H}$ & $\mathrm{F}$ & $\mathrm{H}$ & $\mathrm{F}$ & $48 \mathrm{~h}$ & $12 \mathrm{~min}$ & 16 & 46 \\
3c & $\mathrm{N}$ & $\mathrm{CH}$ & $\mathrm{Br}$ & $\mathrm{H}$ & $\mathrm{F}$ & $\mathrm{H}$ & $\mathrm{F}$ & $48 \mathrm{~h}$ & $12 \mathrm{~min}$ & 60 & 85 \\
3d & $\mathrm{N}$ & $\mathrm{N}$ & $\mathrm{Me}$ & $\mathrm{H}$ & $\mathrm{Cl}$ & $\mathrm{Me}$ & $\mathrm{F}$ & $48 \mathrm{~h}$ & $12 \mathrm{~min}$ & 38 & 65 \\
3e & $\mathrm{N}$ & $\mathrm{N}$ & $\mathrm{Me}$ & $\mathrm{Me}$ & $\mathrm{Cl}$ & $\mathrm{H}$ & $\mathrm{Cl}$ & $48 \mathrm{~h}$ & $12 \mathrm{~min}$ & 38 & 56 \\
\hline
\end{tabular}

A: conventional heating. B: microwave irradiation.

\section{Scheme 3}

\section{Experimental Section}

General Procedures. All microwave-assisted reactions were carried out in a CEM Focused Microwave Synthesis System, Model Discover working at the potency necessary for refluxing under atmospheric conditions (i.e. 250-300W). Melting points were determined on a Kofler hot stage apparatus and are uncorrected. Elemental analyses $(\mathrm{C}, \mathrm{H}, \mathrm{N})$ were carried out on a Carlo Erba Model 1106 Elemental Analyzer and the results are within $\pm 0.4 \%$ of the theoretical values. Merck silica gel $60 \mathrm{~F}_{254}$ plates were used for analytical TLC; column chromatography was performed on Merck silica gel 60 (230-400 mesh). ${ }^{1} \mathrm{H}$-NMR spectra were recorded in $\mathrm{CDCl}_{3}$ on a Varian Gemini-300 spectrometer. Chemical shifts were expressed in $\delta$ (ppm) relative to TMS as internal standard and coupling constants $(\mathrm{J})$ in $\mathrm{Hz}$.

\section{Synthesis of 1-aryl-1H,3H-thiazolo[3,4-a]benzimidazoles (1a-e)}

\section{A) By conventional heating}

2-Mercaptoacetic acid (16 mmol) and appropriate aromatic aldehyde (8 mmol) were added to a stirred solution of (un)substituted 1,2-phenylenediamine ( $8 \mathrm{mmol}$ ) in dry benzene (50 $\mathrm{mL})$ and 
the reaction mixture was refluxed for $48 \mathrm{~h}$. The compounds obtained were isolated as reported in references 5-8.

\section{B) By microwave heating}

2-Mercaptoacetic acid (2 mmol), the appropriate aromatic aldehyde (1 mmol) and (un)substituted 1,2-phenylenediamine $(1 \mathrm{mmol})$ in dry toluene $(3 \mathrm{~mL})$ were placed in a cylindrical quartz tube $(\varnothing 2 \mathrm{~cm})$. The reaction mixture was then stirred and irradiated in a microwave oven at $280 \mathrm{~W}$ for $12 \mathrm{~min}$ at $110^{\circ} \mathrm{C}$. After cooling and adding ethyl acetate $(30 \mathrm{~mL})$, the mixture was neutralized with a solution of sodium hydrogen carbonate. The organic phase was dried $\left(\mathrm{Na}_{2} \mathrm{SO}_{4}\right)$ and the solvent removed under reduced pressure to give an oily residue which was chromatographed on

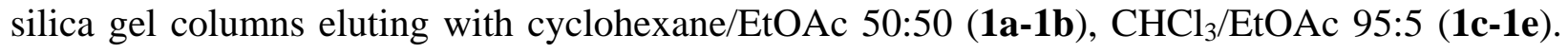
All compounds were crystallized from ethanol.

1-(2,6-Difluorophenyl)-1H,3H-thiazolo-[3,4-a]benzimidazole (1a). Reagents: 1,2-phenylenediamine (108 mg), 2-mercaptoacetic acid (184 mg), 2,6-difluorobenzaldehyde (142 mg). Yield: $173 \mathrm{mg}, 60 \%$; mp $142-143^{\circ} \mathrm{C}\left(140-142^{\circ} \mathrm{C}\right.$ lit. $\left.{ }^{6}\right) .{ }^{1} \mathrm{H}-\mathrm{NMR}: 4.30$ (d, $\left.1 \mathrm{H}, \mathrm{J}=14.3,3-\mathrm{H}_{\mathrm{A}}\right), 4.57$ (dd, $1 \mathrm{H}, \mathrm{J}=1.8$ and 14.3, 3- $\left.\mathrm{H}_{\mathrm{B}}\right), 6.73-7.76(\mathrm{~m}, 8 \mathrm{H}, \mathrm{ArH}$ and $\mathrm{H}-1)$. Anal calcd. for $\mathrm{C}_{15} \mathrm{H}_{10} \mathrm{~F}_{2} \mathrm{~N}_{2} \mathrm{~S}$ : C, 62.49; H, 3.50; N, 9.72; Found: C, 62.59; H, 3.35; N, 9.87.

1-(3-Nitrophenyl)-1H,3H-thiazolo[3,4-a]benzimidazole (1b). Reagents: 1,2-phenylenediamine (108 mg), 2-mercaptoacetic acid (184 mg), 3-nitrobenzaldehyde (151 mg). Yield: 148 mg, 50\%; mp $181^{\circ} \mathrm{C}\left(180-181^{\circ} \mathrm{C} \mathrm{lit}{ }^{5}\right) .{ }^{1} \mathrm{H}-\mathrm{NMR}: 4.41$ (d, 1H, J=14.3, 3- $\left.\mathrm{H}_{\mathrm{A}}\right), 4.57$ (dd, $1 \mathrm{H}, \mathrm{J}=1.7$ and 14.3, 3- $\mathrm{H}_{\mathrm{B}}$ ), 6.58 (s, $1 \mathrm{H}, \mathrm{H}-1$ ), 6.67-8.32 (m, 8H, ArH). Anal calcd. for $\mathrm{C}_{15} \mathrm{H}_{11} \mathrm{~N}_{3} \mathrm{O}_{2} \mathrm{~S}$ : C, 60.59; $\mathrm{H}$, 3.73; N, 14.13; Found: C, 60.44; H, 3.85; N, 14.00 .

1-(2,6-Difluorophenyl)-6,7-dimethyl-1H,3H-thiazolo[3,4-a]benzimidazole (1c). Reagents: 4,5-dimethyl-1,2-phenylenediamine (136 mg), 2-mercaptoacetic acid (184 mg), 2,6difluorobenzaldehyde (142 mg). Yield: $126 \mathrm{mg}, 40 \%$; mp $178-179^{\circ} \mathrm{C}\left(175-177^{\circ} \mathrm{C}\right.$ lit $\left.^{7}\right) .{ }^{1} \mathrm{H}-\mathrm{NMR}$ : 2.25 (s, 3H, $\mathrm{CH}_{3}-7$ ), 2.32 (s, 3H, $\mathrm{CH}_{3}-6$ ), 4.40 (d, 1H, J=14.6, $\mathrm{H}_{\mathrm{A}}-3$ ), 4.65 (dd, 1H, J=2.1 and 14.6, $\mathrm{H}_{\mathrm{B}}-3$ ), 6.74-7.51 (m, 6H, ArH and $\mathrm{H}-1$ ). Anal calcd. for $\mathrm{C}_{17} \mathrm{H}_{14} \mathrm{~F}_{2} \mathrm{~N}_{2} \mathrm{~S}$ : C, 64.54; H, 4.46; N, 8.85; Found: C, 64.67; H, 4.32; N, 9.01.

1-(2,6-Difluorophenyl)-5-methyl-1H,3H-thiazolo[3,4-a]benzimidazole (1d). Reagents: 4methyl-1,2-phenylenediamine (122 mg), 2-mercaptoacetic acid (184 mg), 2,6difluorobenzaldehyde (142 mg). Yield: $193 \mathrm{mg}, 64 \%$; mp $159-161^{\circ} \mathrm{C}\left(160-162^{\circ} \mathrm{C} \mathrm{lit}^{8}\right) .{ }^{1} \mathrm{H}-\mathrm{NMR}$ : 2.65 (s, 3H, $\mathrm{CH}_{3}-5$ ), 4.37 (d, 1H, J=14.2, $\mathrm{H}_{\mathrm{A}}-3$ ), 4.65 (dd, $1 \mathrm{H}, \mathrm{J}=1.9$ and 14.2, $\mathrm{H}_{\mathrm{B}}-3$ ), 6.80-7.34 (m, 7H, ArH and $\mathrm{H}-1$ ). Anal calcd. for $\mathrm{C}_{16} \mathrm{H}_{12} \mathrm{~F}_{2} \mathrm{~N}_{2} \mathrm{~S}$ : C, 63.58; H, 4.00; N, 9.27; Found: C, 63.46; H, 4.23; N, 9.33.

1-(2,6-Difluorophenyl)-8-methyl-1H,3H-thiazolo[3,4-a]benzimidazole (1e). Reagents: 4methyl-1,2-phenylenediamine (122 mg), 2-mercaptoacetic acid (184 mg), 2,6difluorobenzaldehyde (142 mg). Yield: $48 \mathrm{mg}, 16 \%$; mp $148-150^{\circ} \mathrm{C}\left(146-149^{\circ} \mathrm{C} \mathrm{lit}^{8}\right) .{ }^{1} \mathrm{H}-\mathrm{NMR}$ : 2.30 (s, 3H, $\mathrm{CH}_{3}-8$ ), 4.28 (d, $1 \mathrm{H}, \mathrm{J}=14.3, \mathrm{H}_{\mathrm{A}}-3$ ), 4.60 (dd, $1 \mathrm{H}, \mathrm{J}=1.7$ and 14.3, $\mathrm{H}_{\mathrm{B}}-3$ ), 6.88-7.56 (m, 7H, ArH and $\mathrm{H}-1$ ). Anal calcd. for $\mathrm{C}_{16} \mathrm{H}_{12} \mathrm{~F}_{2} \mathrm{~N}_{2} \mathrm{~S}$ : C, 63.58; H, 4.00; N, 9.27; Found: C, 63.78; H, 4.12; N, 9.08. 


\section{Synthesis of 2-aryl-1-benzylbenzimidazoles (2a-2b)}

\section{A) By conventional heating}

p-Toluenesulfonic acid (16 mmol) and appropriate aromatic aldehyde $(16 \mathrm{mmol})$ were added to a stirred solution of 1,2-phenylenediamine $(8 \mathrm{mmol})$ in ethanol $(80 \mathrm{~mL})$. The reaction mixture was refluxed for $2 \mathrm{~h}$. The conventional work-up was carried out as described in reference 9.

\section{B) By microwave heating}

A mixture of p-toluenesulfonic acid (344 mg, $2 \mathrm{mmol}$ ), 2,6-difluorobenzaldehyde (284 mg, $2 \mathrm{mmol}$ ) and 1,2-phenylenediamine (108 mg, $1 \mathrm{mmol}$ ) without solvent for 2a or 4,5-dimethyl1,2-phenylenediamine (136 mg, $1 \mathrm{mmol}$ ) in ethanol (3 mL) for $\mathbf{2} \mathbf{b}$, were stirred and irradiated in a microwave oven at $250 \mathrm{~W}$ for $6 \mathrm{~min}$ at $90^{\circ} \mathrm{C}$. After cooling and adding of ethanol $(10 \mathrm{~mL})$ and water $(20 \mathrm{~mL})$, the reaction mixture was extracted with chloroform (3 x $20 \mathrm{~mL})$. The collected organic phases were dried over sodium sulfate and the solvent evaporated under reduced pressure. The oily residue was treated with diethyl ether to afford, after recrystallization from ethanol, derivative $\mathbf{2 b}$, or separated by silica gel column chromatography eluting with cyclohexane/ethyl acetate 4:6 to give $2 \mathbf{a}$ which was crystallized from ethanol.

1-(2,6-Difluorobenzyl)-2-(2,6-difluorophenyl)-benzimidazole (2a). Yield 249 mg, 70\%; mp ${ }^{\circ} \mathrm{C}$ 105-106 (103-105 ${ }^{\circ} \mathrm{C}$ lit $\left.^{9}\right) .{ }^{1} \mathrm{H}-\mathrm{NMR}$ : 5.38 (s, 2H, $\mathrm{CH}_{2}$ ), 6.79-7.87 (m, 10H, ArH). Anal. calcd for $\mathrm{C}_{20} \mathrm{H}_{12} \mathrm{~F}_{4} \mathrm{~N}_{2}$ : C, 67.42; H, 3.39; N, 7.86; Found C, 67.81; H, 3.05; N, 7.94.

1-(2,6-Difluorobenzyl)-2-(2,6-difluorophenyl)-5,6-dimethylbenzimidazole (2b). Yield $276 \mathrm{mg}, 72 \%$; mp $192^{\circ} \mathrm{C}\left(189-191^{\circ} \mathrm{C}\right.$ lit. $\left.{ }^{9}\right) .{ }^{1} \mathrm{H}-\mathrm{NMR}: 2.36$ and 2.38 (2s, 6H, $\left.\mathrm{CH}_{3}\right), 5.31$ (s, 2H, $\mathrm{CH}_{2}$ ), 6.76-7.58 (m, 8H, ArH). Anal. calcd for $\mathrm{C}_{22} \mathrm{H}_{16} \mathrm{~F}_{4} \mathrm{~N}_{2}$ : C, 68.75; H, 4.20; N, 7.29; Found: 68.41; H, 4.39; N, 7.66.

\section{Synthesis of 2,3-diaryl-1,3-thiazolidin-4-ones (3a-3e)}

\section{A) By conventional heating}

2-Mercaptoacetic acid (16 mmol) and appropriate aromatic aldehyde (8 mmol) were added to a stirred solution of (hetero)aromatic amine $(8 \mathrm{mmol})$ in dry toluene $(50 \mathrm{~mL})$ and the obtained mixture was refluxed for $48 \mathrm{~h}$. The products were purified as reported in references 10-12.

\section{B) By microwave heating}

A mixture of 2-mercaptoacetic acid (2 mmol), appropriate aromatic aldehyde $(1 \mathrm{mmol})$ and (hetero)aromatic amine $(1 \mathrm{mmol})$ in dry toluene $(3 \mathrm{~mL})$ were stirred and irradiated in a microwave oven at $280 \mathrm{~W}$ for $12 \mathrm{~min}$ at $110^{\circ} \mathrm{C}$. After cooling and adding ethyl acetate (30 mL), the mixture was neutralized with a solution of sodium hydrogen carbonate and dried $\left(\mathrm{Na}_{2} \mathrm{SO}_{4}\right)$. After removal of the solvent under reduced pressure, the oily residue was treated with diethyl ether to afford a solid which was recrystallized from ethanol to give derivatives 3a, 3d and 3e. The remaining compounds were isolated by silica gel column chromatography eluting with chloroform and then crystallized from ethanol.

2-(2,6-Dichlorophenyl)-3-(3-methylphenyl)-1,3-thiazolidin-4-one (3a). Reagents: 3-methylaniline (107 mg), 2-mercaptoacetic acid (184 mg), 2,6-dichlorobenzaldehyde (175 mg). Yield: $269 \mathrm{mg}$, 72\%; mp 131-133 ${ }^{\circ} \mathrm{C}\left(129-132^{\circ} \mathrm{C}\right.$ lit. $\left.{ }^{11}\right)$; ${ }^{1} \mathrm{H}-\mathrm{NMR}: 2.28$ (s, 3H, $\left.\mathrm{CH}_{3}\right), 3.95$ (d, 1H, J=15.4, 5-H , 
4.08 (dd, 1H, J=2.5 and 15.4, 5- $\mathrm{H}_{\mathrm{B}}$ ), 6.96-7.28 (m, 8H, ArH and H-2). Anal. calcd for $\mathrm{C}_{16} \mathrm{H}_{13} \mathrm{Cl}_{2} \mathrm{NOS}$ : C, 56.81; H, 3.87; N, 4.14; Found: C, 56.61; H, 4.05; N, 4.24.

2-(2,6-Difluorophenyl)-3-(3-methoxyphenyl)-1,3-thiazolidin-4-one (3b). Reagents: 3-methoxyaniline (123 mg), 2-mercaptoacetic acid (184 mg), 2,6-difluorobenzaldehyde (142 mg). Yield: $148 \mathrm{mg}$, 46\%; mp 99-101 ${ }^{\circ} \mathrm{C}\left(100-102^{\circ} \mathrm{C} \mathrm{lit.}^{11}\right)$; ${ }^{1} \mathrm{H}-\mathrm{NMR}: 3.73$ (s, 3H, $\left.\mathrm{OCH}_{3}\right), 3.86\left(\mathrm{~d}, 1 \mathrm{H}, \mathrm{J}=15.4,5-\mathrm{H}_{\mathrm{A}}\right)$, 4.12 (dd, $1 \mathrm{H}, \mathrm{J}=2.0$ and 15.4, 5- $\mathrm{H}_{\mathrm{B}}$ ), 6.55 (d, 1H, J=2.0, H-2), 6.72-7.24 (m, 7H, ArH). Anal. calcd for $\mathrm{C}_{16} \mathrm{H}_{13} \mathrm{~F}_{2} \mathrm{NO}_{2} \mathrm{~S}$ : C, 59.80; H, 4.08; N, 4.36; Found: C, 59.90; H, 3.93; N, 4.56.

3-(6-Bromopyridin-2-yl)-2-(2,6-difluorophenyl)- 1,3-thiazolidin-4-one (3c). Reagents: 2-amino6-bromopyridine (173 mg), 2-mercaptoacetic acid (184 mg), 2,6-difluorobenzaldehyde (142 mg). Yield: $346 \mathrm{mg}, 85 \%$; mp $129-131^{\circ} \mathrm{C}\left(126-130^{\circ} \mathrm{C}\right.$ lit. $\left.{ }^{10}\right) ;{ }^{1} \mathrm{H}$ NMR: 3.84 (d, $\left.1 \mathrm{H}, \mathrm{J}=15.9,5-\mathrm{H}_{\mathrm{A}}\right)$, 4.23 (dd, 1H, J=1.4 and 15.9, 5- $\mathrm{H}_{\mathrm{B}}$ ), 6.86 (m, 2H, H-3',5'), 7.08 (d, 1H, J=1.4, H-2), 7.16-7.25 (m, 2H, H-4' and $\mathrm{H}_{5}-\mathrm{Py}$ ), 7.52 (dd, $1 \mathrm{H}, \mathrm{J}=7.9$ and 8.2, $\mathrm{H}_{4}-\mathrm{Py}$ ), 8.29 (d, 1H, J=8.2, $\mathrm{H}_{3}-\mathrm{Py}$ ). Anal. calcd for $\mathrm{C}_{14} \mathrm{H}_{9} \mathrm{BrF}_{2} \mathrm{~N}_{2} \mathrm{OS}$ : C, 46.52; H, 3.38; N, 7.23; Found: C, 46.77; H, 3.24; N, 7.49.

2-(2-Chloro-6-fluoro-3-methylphenyl)-3-(4-methylpyrimidin-2-yl)-1,3-thiazolidin-4-one (3d). Reagents: 2-amino-4-methylpyrimidine (109 mg), 2-mercaptoacetic acid (184 mg), 2-chloro-6fluoro-3-methylbenzaldehyde (172 mg). Yield $242 \mathrm{mg}, 65 \%$; mp $126^{\circ} \mathrm{C}$ dec. $\left(126^{\circ} \mathrm{C}\right.$ dec. lit. $\left.{ }^{12}\right)$; ${ }^{1} \mathrm{H}-\mathrm{NMR}$ : 2.17 and 2.39 (2s, 6H, $\mathrm{CH}_{3}$ ), 3.89 (d, 1H, J=15.7, 5- $\mathrm{H}_{\mathrm{A}}$ ), 4.23 (dd, 1H, J=1.9 and 15.7, 5- $\mathrm{H}_{\mathrm{B}}$ ), 6.86-8.51 (m, 5H, ArH and $\mathrm{H}-2$ ). Anal. calcd for $\mathrm{C}_{16} \mathrm{H}_{13} \mathrm{ClFN}_{3} \mathrm{OS}$ : C, 51.77; H, 3.72; N, 12.94; Found C, 51.79; H, 3.62; N, 12.96.

2-(2,6-Dichlorophenyl)-3-(4,6-dimethylpyrimidin-2-yl)-1,3-thiazolidin-4-one (3e). Reagents: 2-amino-4,6-dimethylpyrimidine (123 mg), 2-mercaptoacetic acid (184 mg), 2,6dichlorobenzaldehyde (175 mg). Yield: $218 \mathrm{mg}, 56 \%$; mp 200-202 ${ }^{\circ} \mathrm{C}\left(198-201^{\circ} \mathrm{C}\right.$ lit. $\left.{ }^{13}\right) ;{ }^{1} \mathrm{H}-$ NMR: 2.37 (s, 6H, Me), 3.95 (d, 1H, J=15.7, 5- $\mathrm{H}_{\mathrm{A}}$ ), 4.18 (dd, 1H, J=1.9 and 15.7, 5- $\mathrm{H}_{\mathrm{B}}$ ), 6.707.30 (m, 4H, ArH), 7.49 (d, $1 \mathrm{H}, \mathrm{J}=1.9, \mathrm{H}-2$ ). Anal. calcd for $\mathrm{C}_{15} \mathrm{H}_{13} \mathrm{Cl}_{2} \mathrm{~N}_{3} \mathrm{OS}$ : C, 50.86; $\mathrm{H}, 3.70$; N, 11.86; Found: C, 50.77; H, 3.82; N, 11.70.

\section{Acknowledgements}

This work was supported in part by the Ministero dell'Istruzione, dell’Università e della Ricerca (MIUR, COFIN 2002).

\section{References}

1. A. Loupy, Ed. Microwaves in organic synthesis; Wiley-VCH Verlag Gmbh \& Co. KGaA: Weinhein, 2002.

2. B. L. Hayes, In Microwave synthesis: chemistry at the speed of light; CEM Publishing: Matthews, USA, 2002.

3. Jonckheere, H.; Anné, J.; De Clercq, E. Med. Res. Rev. 2000, 20, 129. 
4. Vella, S.; Palmisano, L. Antiviral Res. 2000, 45, 1.

5. Chimirri, A.; Grasso, S.; Monforte, A. M.; Monforte, P.; Zappalà, M. Il Farmaco 1991, 46, 817.

6. Chimirri, A.; Grasso, S.; Monforte, A. M.; Monforte, P.; Zappalà, M. Il Farmaco 1991, 46, 925.

7. Chimirri, A.; Grasso, S.; Molica, C.; Monforte, A. M.; Monforte, P.; Zappalà, M. Il Farmaco 1996, 51, 279.

8. Chimirri, A.; Grasso, S.; Monforte, P.; Rao, A.; Zappalà, M.; Monforte, A. M.; Pannecouque, C.; Witvrouw, M.; Balzarini, J.; De Clercq, E. Antiviral Chem. Chemother. 1999, 10, 211.

9. Rao, A.; Chimirri, A.; De Clercq, E.; Monforte, A. M.; Monforte, P.; Pannecouque C.; Zappalà, M. Il Farmaco 2002, 57, 819.

10. Barreca, M. L.; Balzarini, J.; Chimirri, A.; De Clercq, E.; De Luca, L.; Höltje, H. D.; Höltje, M.; Monforte, A. M.; Monforte, P.; Pannecouque C.; Rao, A.; Zappalà, M. J. Med. Chem. 2002, 45, 5410.

11. Rao, A.; Carbone, A.; Chimirri, A.; De Clercq, E.; Monforte, A. M.; Monforte, P.; Pannecouque C.; Zappalà, M. Il Farmaco 2003, 58, 115.

12. Rao, A.; Balzarini, J.; Carbone, A.; Chimirri, A.; De Clercq, E.; Monforte, A. M.; Monforte, P.; Pannecouque C.; Zappalà, M. Il Farmaco 2004, 59, 33.

13. Rao, A.; Balzarini, J.; Carbone, A.; Chimirri, A.; De Clercq, E.; Monforte, A. M.; Monforte, P.; Pannecouque, C.; Zappalà, M. Antiviral Res. submitted for the publication.

14. Reddy, A. C. S.; Rao, P. S.; Venkataratnam, R. V. Tetrahedron Lett. 1996, 37, 2845. 